\title{
Yuridis Pemberian Kredit Bank dengan Jaminan Hak Tanggungan pada PT. Bank Mestika Dharma, Medan
}

\section{Juridical Review of Bank Credit with Mortgage Rights Guarantee at PT. Bank Mestika Dharma, Medan}

\author{
Evelin Wijaya* , Fendy \& Aisyah \\ Jurusan Ilmu Hukum, Fakultas Hukum, Universitas Prima Indonesia
}

Diterima: 31 Agustus 2020; Direview: 01 September 2020; Disetujui:13 September 2020

*email: evelinloiswijaya@gmail.com

\begin{abstract}
Abstrak
Tujuan penelitian ini adalah untuk meneliti kebijakan dalam pemberian kredit yang dilakukan PT. Bank Mestika Dharma, TBK berikut hubungan hukum dalam perjanjian kredit terhadap jaminan hak tanggungan yang diikat serta untuk mengetahui kepastian hukum bagi kreditur pemegang hak tanggungan. Dalam penelitian ini, metode yang digunakan bersifat deskriptif analitis dimana fakta-fakta yang ditemukan digambarkan secara umum beserta ketentuan-ketentuan hukumnya. Penelitian yang dilakukan yaitu dengan melakukan penelitian lapangan dan penelitian kepustakaan dengan melihat permasalahan secara langsung di lapangan yang kemudian dibandingkan dengan perundang-undangan dan/atau peraturan pelaksanaannya yang terkait dengan pengikatan hak tanggungan tersebut. Melalui hasil penelitian ini diketahui bahwa pengikatan objek jaminan sangatlah penting bagi semua lembaga keuangan yang melakukan fungsinya sebagai intermediasi. Pada PT. Bank Mestika Dharma, TBK, setiap pemberian kredit haruslah dibuatkan suatu perjanjian kredit dengan mengikat suatu jaminan tertentu, salah satunya adalah dengan Hak Tanggungan atas tanah seperti yang diatur dalam Undang-Undang Nomor 4 Tahun 1996 tentang Hak Tanggungan Atas Tanah Beserta Benda-benda Yang Berkaitan Dengan Tanah, dimana hak tersebut akan memberikan hak kepada kreditur pemegang hak untuk didahulukan dalam memperoleh pelunasan atas tagihannya dari hasil penjualan benda tertentu milik debitur sebesar nilai yang diikat dibandingkan kreditur lainnya dalam membayar kewajibannya.
\end{abstract}

Kata Kunci: Kredit; Jaminan; Hak Tanggungan

\begin{abstract}
The purpose of this study is to examine the policies of granting credit in PT. Bank Mestika Dharma, TBK along with bonded legality of credit agreement with mortgage guarantee and to find out legal certainty for creditors who hold mortgage rights guarantee. The method of this research is descriptive analytic where the facts found are described in general along with their legal provisions. This research is carried out by doing on the spot and books research by looking the problems and compared with laws and/or implementing regulations which related to the binding of these mortgage rights guarantee. The results of this research is knowing that the collateral binding is very important for all financial institutions which perform their function as intermediation. In PT. bank Mestika Dharma, TBK, every credit must have credit agreement by binding certain guarantees, one of them is mortgage rights guarantee as regulated in UU No.4 in 1996 where this right will give creditor who have this mortgage rights guarantee to take precedence in obtaining payment of the claim from the sale of objects belonging to the debtor and based on the binding value rather than othe creditors in paying their obligation.
\end{abstract}

Keywords: Credit; Collateral; Mortgage Guarantee

How to Cite: Evelin, W., Fendy \& Aisyah, (2020). Tinjauan Yuridis Pemberian Kredit Bank dengan Jaminan Hak Tanggungan (Studi Pada PT. Bank Mestika Dharma, Tbk; Kantor Pusat Medan). Journal of Education, Humaniora and Social Sciences (JEHSS). 3(2): 412-418. 


\section{PENDAHULUAN}

Dalam menciptakan masyarakat yang adil dan Makmur, peningkatan taraf kehidupan dengan mengembangkan dunia perekonomian dan perdagangan merupakan salah satu upaya yang dilakukan untuk memacu pertumbukan ekonomi yaitu dengan memberikan kesempatan terutama bagi para pengusaha. Dukungan yang diberikan pemerintah dalam menggairahkan dan mendongkrak dunia usaha yaitu dengan penyediaan berbagai sarana yang didalamnya upaya untuk menunjang permodalan yaitu dengan penyediaan fasilitas kredit. Dalam hal ini, fungsi dari lembaga keuangan dituntut untuk lebih meningkat yaitu sebagai penggerak perekonomian dan sarana mobilitas yang efektif juga sebagai penyalur dana untuk pembiayaan kegiatan produktif.

Sejalan dengan hal di atas, menurut Kartono (1995): "Memperhatikan pertumbuhan dan perkembangan dunia usaha sekarang ini, para pengusaha dalam upaya menambah kebutuhan akan modal yang mendorong kelancaran usahanya biasanya memanfaatkan fasilitas kredit yang disediakan oleh pemerintah dan disalurkan melalui lembaga-lembaga keuangan dengan mengadakan perjanjian kredit". Dari penjelasan tersebut jelaslah bahwa bank menyediakan dana bagi masyarakat yang kemudian dapat dimanfaatkan sebagai modal dalam menjalankan kegiatan-kegiatan usahanya.

Pentingnya fungsi perbankan dan perannya yang penuh risiko karena aktivitas utamanya mengandalkan dana titipan masyarakat baik dalam bentuk tabungan, giro maupun deposito. Peran yang diemban oleh sektor perbankan yang sangatlah penting, membuat bank tidak membuka keran yang bebas dalam menyalurkan kreditnya tanpa keyakinan berdasarkan analisis serta jaminan yang kuat sebagai back-up apabila sang kreditur wanprestasi atau tidak membayar pinjamannya kepada bank (Fauzi, 2019; Nainggolane t al., 2012; Jamilah. 2017; Sipayung et al., 2019).

Dalam pemberian kredit pada PT. Bank Mestika Dharma, TBK, haruslah dibuatkan suatu perjanjian kredit dengan mengikat suatu jaminan tertentu. Pengertian jaminan utang adalah pemberian keyakinan kepada pihak kreditor atas pembayaran utang-utang yang telah dari suatu perjanjian yang bersifat assecoir (perjanjian ikutan) terhadap perjanjian pokoknya, berupa perjanjian yang menerbitkan utang piutang (Fuady, 2013). Salah satunya adalah jaminan Hak Tanggungan atas tanah seperti yang diatur dalam Undang-Undang Nomor 4 Tahun 1996 tentang Hak Tanggungan Atas Tanah Beserta Benda-benda Yang Berkaitan Dengan Tanah dimana dalam pasal 1 angka 1 disebutkan bahwa "Hak Tanggungan atas tanah beserta benda-benda yang berkaitan dengan tanah, yang selanjutnya disebut Hak tanggungan, adalah hak jaminan yang dibebankan pada hak atas tanah sebagaimana dimaksud dalam Undang-Undang Nomor 5 tahun 1960 tentang Peraturan Dasar Pokok-Pokok Agraria, berikut atau tidak berikut benda-benda lain yang merupakan satu kesatuan dengan tanah itu, untuk pelunasan utang tertentu, yang memberikan kedudukan yang diutamakan kepada kreditur tertentu terhadap kreditur-kreditur lain".

\section{METODE PENELITIAN}

Penelitian ini bersifat deskriptif analitis yaitu menggambarkan fakta-fakta yang ditemukan secara umum termasuk ketentuan-ketentuan hukumnya, kemudian dilakukan analisis terhadap praktik hubungan hukum antara kreditur dan debitur beserta teori - teori hukumnya dengan menggunakan metode pendekatan yuridis normatif yaitu pendekatan terhadap suatu masalah dengan mengacu pada ketentuan-ketentuan yang berlaku, dimana penulis melakukan pengkajian terhadap Undang-Undang Nomor 4 Tahun 1996 tentang hak tanggungan atas tanah beserta benda-benda yang berkaitan dengan tanah.

Terdapat dua cara yang penulis pakai untuk melakukan penelitian ini, yaitu :

1. Penelitian kepustakaan yaitu pencarian data yang dilakukan dengan mempelajari dan mengkaji peraturan perundang- undangan dan relevansinya serta dari buku - buku referensi.

2. Penelitian lapangan yaitu penelitian yang dilakukan secara langsung ke lapangan di tempat permasalahan yaitu PT Bank Mestika Dharma, Tbk Kantor Pusat Medan. 
Evelin Wijaya, Fendy \& Aisyah, Yuridis Pemberian Kredit Bank dengan Jaminan Hak Tanggungan pada PT. Bank

Mestika Dharma, Medan

\section{HASIL DAN PEMBAHASAN}

Kebijakan dalam pemberian kredit yang dilakukan pada PT. Bank Mestika Dharma, Tbk

Fungsi perbankan seperti yang dijelaskan dalam Undang-Undang RI No.10 tahun 1998 bahwa "Bank merupakan badan usaha yang menghimpun dana dari masyarakat dalam bentuk simpanan dan menyalurkannya kepada masyarakat dalam bentuk kredit dan atau bentuk-bentuk lainnya dalam rangka meningkatkan taraf hidup rakyat banyak". Secara etimologis istilah kredit berasal dari bahasa Latin, credere, yang berarti kepercayaan (Hermansyah, 2014). Seseorang yang memperoleh kredit berarti memperoleh kepercayaan, dengan kata lain kepercayaan adalah dasar dari kredit (Soerjadi dalam Sutedi, 2010). Pengaturan tentang kredit di Indonesia mengacu kepada ketentuan hukum perbankan. Pengertian tentang kredit sendiri ditemukan dalam pasal 1 angka 11 Undang-Undang Republik Indonesia Nomor 7 Tahun 1992 tentang Perbankan sebagaimana telah diubah dengan Undang-Undang Nomor 10 Tahun 1998 (selanjutnya disebut Undang-Undang Perbankan), yaitu:

"Kredit adalah penyediaan uang atau tagihan yang dipersamakan dengan itu, berdasarkan persetujuan atau kesepakatan KUH antara bank dengan pihak lain yang mewajibkan pihak peminjam untuk melunasi utangnya setelah jangka waktu tertentu dengan pemberian bunga."

Menurut Raymond P.Kent (1991:13) kredit adalah hak untuk menerima pembayaran atau kewajiban untuk melakukan pembayaran pada waktu diminta atau pada waktu yang akan datang, karena penyerahan barang-barang sekarang. Sementara menurut Thomas Suyanto (1991), kredit berarti pihak kesatu memberikan prestasi baik berupa barang, uang atau jasa kepada pihak lain, sedangkan kontraprestasi akan diterima kemudian (dalam jangka waktu tertentu). Dengan demikian, dapat disimpulkan bahwa kredit adalah kesepakatan pinjammeminjam antara bank dan pihak lain yang mewajibkan peminjam untuk melunasi utangnya setelah jangka waktu tertentu dengan jumlah bunga, imbalan atau pembagian hasil keuntungan.

Sebagai lembaga keuangan, pemberian kredit oleh bank tentunya sarat akan resiko, maka Bank wajib untuk mengelola resiko tersebut, oleh karena itu diperlukan adanya manajemen resiko. Manajemen resiko diartikan sebagai serangkaian metodologi dan prosedur yang digunakan untuk mengidentifikasi, mengukur, memantau, dan mengendalikan risiko yang timbul dari seluruh kegiatan usaha Bank. (Usanti, 2017)

Pada PT. Bank Mestika Dharma, Tbk, dalam mencegah terjadinya kredit bermasalah di kemudian hari, maka penilaian untuk memberikan persetujuan terhadap suatu permohonan kredit dilakukan dengan berpedoman kepada 5 hal yang juga kita kenal sebagai 5C, yaitu character (kepribadian) yaitu penilaian karakter atau watak dari calon debitur, capacity (kemampuan) yaitu menilai kemampuan debitur dalam menjalankan usahanya, capital (modal) yaitu penilaian keuangan debitur, prediksi mengenai prospek usaha dan kinerja usaha debitur hal ini mempunyai kolerasi langsung terhadap tingkat kemampuan bayar debitur, condition (kondisi) kondisi disini adalah kondisi perekonomian debitur secara mikro maupun makro, dan collateral (agunan) yaitu harta milik debitur yang digunakan sebagai jaminan bagi pelunasan utangnya jika kredit dalam keadaan macet (Fuady, 2002). Penerapkan 5C dalam setiap penyaluran kredit merupakan wujud dari prinsip kehati-hatian bank diharapkan dapat menempatkan kredit pada kualitas kredit yang baik atau performing loan.

Pada PT. Bank Mestika Dharma, Tbk dalam pemberian kredit bank dimulai dari permohonan kredit dari nasabah debitur kepada bank dengan mengisi form permohonan kredit dan menyertakan beberapa data yang diperlukan, setelah itu dilanjutkan dengan keputusan kredit setelah sebelumnya dilakukan analisis terhadap semua data yang diberikan debitur termasuk penilaian terhadap $5 \mathrm{C}$ debitur terlebih dahulu serta membandingkan kemampuan membayar debitur dengan jumlah pinjaman yang diajukan. Setelah adanya keputusan dari pihak bank terhadap pencairan kredit tersebut, maka akan dilanjutkan dengan pembuatan perjanjian kredit (PK) yang kemudian dilanjutkan dengan pengikatan terhadap jaminan kredit. 


\section{Hubungan Hukum dalam Perjanjian Kredit terhadap Jaminan Hak Tanggungan}

Menurut Ch. Gatot Wardoyo (2000), perjanjian kredit mempunyai beberapa fungsi, yaitu: (1) sebagai perjanjian pokok, artinya perjanjian kredit merupakan sesuatu yang menentukan batal atau tidak batalnya perjanjian lain yang mengikutinya, misalnya perjanjian pengikatan jaminan; (2) sebagai alat bukti mengenai batasan-batasan hak dan kewajiban di antara kreditur dan debitur; dan (3) sebagai alat untuk melakukan monitoring kredit.

Pasal 1754 KUH Perdata tertera definisi dari perjanjian kredit atau perjanjian pinjam meminjam yaitu suatu perjanjian dengan mana pihak yang satu memberikan kepada pihak yang lain suatu jumlah tertentu barang-barang yang bisa habis karena pemakaian, dengan syarat bahwa pihak yang terakhir ini akan mengembalikan sejumlah uang yang sama dari jenis dan mutu yang sama pula. (Subekti, 1995).

Dalam penjelasan Pasal 8 Undang-Undang Nomor 10 Tahun 1998 disebutkan bahwa jaminan pemberian kredit dalam arti keyakinan atas kemampuan dan kesanggupan nasabah debitur untuk melunasi kewajibannya sesuai dengan yang diperjanjikan merupakan faktor penting yang harus diperhatikan oleh bank. Untuk memperoleh keyakinan tersebut, bank melakukan penilaian atas jaminan (collateral) sebelum memberikan kredit kepada nasabah debitur dengan memperhatikan prinsip kehati-hatian.

Dengan demikian, barang yang dapat dijadikan jaminan haruslah: (a) suatu benda yang dapat dinilai dengan uang, (b) jaminan tersebut haruslah benda atau hak yang boleh dan dapat dialihkan kepada orang lain (Subekti, 1991), dan (c) nilai kebendaan jaminan secara finasial haruslah lebih tinggi dibanding nilai utangnya. (Usman, 2001). Sehingga jika dilakukan penjualan terhadap objek jaminan tersebut, diharapkan hasil penjualannya dapat mengembalikan seluruh nilai pokok berikut bunga, denda yang terutang, beserta seluruh biaya yang dikeluarkan untuk menguangkan barang jaminan tersebut.

Salah satu hak jaminan yang diterima sebagai pengikatan terhadap jaminan kredit di PT. Bank Mestika Dharma, Tbk yaitu Hak Tanggungan untuk benda tidak bergerak. Jaminan ini diatur dalam Undang-Undang Nomor.4 tahun 1996 tentang Hak Tanggungan Atas Tanah Beserta Benda-benda yang Berkaitan dengan Tanah (UUHT). Merujuk pada ketentuan Angka 4 Penjelasan Umum UUHT antara lain menyatakan:

"Hak Tanggungan adalah hak jaminan atas tanah untuk pelunasan utang tertentu, yang memberikan kedudukan diutamakan kepada kreditur tertentu terhadap kreditur lain. Dalam arti, bahwa jika debitur cedera janji, kreditur pemegang Hak Tanggungan berhak menjual melalui pelelangan umum tanah yang dijadikan jaminan menurut ketentuan peraturan perundangundangan yang bersangkutan, dengan hak mendahulu daripada kreditur-kreditur lain."

Berasarkan uraian dan penjelasan di atas, maka dapat dikatakan bahwa hak jaminan kebendaan adalah hak yang memberikan kepada kreditur pemegang hak tersebut suatu kedudukan yang lebih baik, karena:

(1) Dalam mengambil pelunasan atas tagihannya, kreditur pemegang hak tersebut diduluankan pembayarannya dari hasil penjualan benda-benda tertentu milik debitur yang dijadikan objek jaminan sebagai pelunasan utang debitur; dan/atau

(2) Jaminan umumnya merupakan benda yang berharga bagi debitur itu sendiri. Hal ini dapat memberikan tekanan psikologis kepada debitur untuk melunasi utangnya. Sifat manusia yang berusaha mempertahankan apa yang berharga dan telah dianggap atau diakui telah menjadi miliknya, menjadi dasar hukum jaminan (Satrio, 2007).

Pada PT. Bank Mestika Dharma, Tbk, hak atas tanah yang dibebani Hak Tangungan seperti (1) hak milik, (2) hak guna Usaha, (3) hak guna bangunan, (4) hak pakai dan (5) hak milik atas satuan rumah susun (HMASRS). Pendaftaran hak atas tanah akan menghasilkan: kepastian hak atas tanah, kepastian subjek hak atas tanah, kepastian objek hak atas tanah dan kepastian hukum hak atas tanah (Handayani, 2015).

Dalam hal pengikatan hak tanggungan, proses yang mendahuluinya adalah adanya Perjanjian Kredit (PK) diikuti dengan Akta pemberian Hak Tanggungan (APHT) yang dibuat di PPAT (Pejabat Pembuat Akta tanah). Dalam PK dan APHT harus dicantumkannya segala sesuatu 
tentang kredit berikut pelaksanaanya antara lain adalah jumlah utang si debitur serta tata cara pelunasannya. Dalam PK juga dapat dicantumkan kesepakatan berupa hak dan kewajiban masing-masing pihak berikut solusi apabila debitur wanprestasi (cidera janji) dalam membayar kewajibannya. Kemudian pengajuan pencatatan dan pemasangan Hak Tanggungan di Kantor Pertanahan oleh PPAT yang diberi kuasa oleh bank. Akta Pemberian Hak Tanggungan (APHT), yang tidak didaftarkan ke Kantor Pertanahan, akan mengakibatkan kedudukan kreditor hanya sebagai kreditor konkuren. Upaya hukum yang dapat dilakukan oleh pihak kreditor dengan 2 cara, yaitu: penyelesaian melalui non litigasi dan melalui cara litigasi (Sari, 2015).

Setelah proses tersebut, Kantor Pertanahan mengeluarkan Sertifikat Hak Tanggungan yang berisikan data-data dan keterangan-keterangan yang tercantum dalam APHT. Jadi Sertifikat Hak Tanggungan ini berfungsi sebagai bukti bahwa atas objek tersebut dibebankan hak tanggungan.

Setelah proses pencatatan Hak Tanggungan pada Sertifikat Hak Tanggungan selesai, maka sertifikat asli dan Sertifikat Hak Tanggungan dikembalikan kepada bank yang sebagai kreditur untuk disimpan sampai utangnya dilunasi. Dalam hal sertifikat hak tanggungan sedang dalam pengurusan di notaris, maka bank wajib dibuatkan Cover Note oleh notaris/PPAT yaitu surat keterangan yang diberikan kepada pihak bank yang berisi keterangan bahwa pada tanggal tertentu telah dilaksanakan penandatanganan akta perjanjian kredit dan akta pemberian jaminan antara pihak debitur dan pihak bank serta menyatakan bahwa pengikatan objek jaminan sedang dalam pengurusan. Cover note hanya menjadi pegangan sementara bagi bank hingga diserahkannya seluruh akta dan jaminan yang telah didaftarkan melalui jasa notaris/PPAT. Biasanya pada cover note dicantumkan prediksi tanggal penyelesaian pengikatan objek jaminan tersebut, apabila telah lewat dari tanggal yang tertera maka haruslah dibuatkan cover note yang baru sebagai perpanjangan.

Dalam hal diikatnya hak tanggungan, nilai hak tanggungan yang diikat oleh PT. Bank Mestika Dharma,Tbk adalah sebesar 125\% dari nilai pokok utang. Hal ini dilakukan agar semua nilai pokok dan tunggakan dikemudian hari yang termasuk di dalamnya biaya, bunga, denda, dsb dapat dijangkau. Nilai hak tanggungan adalah penting, karena posisi pemegang hak tanggungan didahulukan (preferen dan separatis) serta diistimewakan dari kreditor lainnya, dalam konteks sebesar nilai hak tanggungan. Apabila nilai hak tanggungan kreditor tidak dapat menjangkau nilai outstanding piutang debitur, status debitur hanyalah sebagai debitur konkruen yang sifatnya "keroyokan" dengan debitur lainnya yang hak pemulihan piutangnya barulah dapat diterima setelah hakim memutuskannya lewat gugatan perdata.

\section{Kepastian Hukum bagi Kreditur Pemegang Jaminan Hak Tanggungan apabila Debitur tidak dapat Membayar Utang}

Undang-undang telah memberikan hak-hak istimewa (privilege) atas pemegang hak-hak jaminan. Kemudahan yang disediakan oleh UUHT bagi para kreditur pemegang Hak Tanggungan manakala debitur cidera janji, berdasarkan Pasal 6 jo. Pasal 20 ayat (1) huruf a dan b serta ayat (2), maka eksekusi atas benda jaminan Hak Tanggungan dapat dilakukan melalui 3 (tiga) cara, yaitu: (1) parate eksekusi; (2) titel eksekutorial; dan (3) penjualan di bawah tangan. Parate eksekusi atau eksekusi langsung dengan menjual objek jaminan milik debitur secara langsung dengan proses lelang tanpa terlebih dahulu mendapatkan penetapan Ketua Pengadilan Negeri terhadap barang jaminan dengan memberikan hak kepada kreditur untuk dapat melaksanakan sendiri parate eksekusi tersebut. Menurut Subekti (1990), "Parate eksekusi adalah menjalankan sendiri atau mengambil sendiri apa yang menjadi haknya, dalam arti tanpa perantaraan hakim, yang ditujukan atau sesuatu barang jaminan untuk selanjutnya menjual sendiri barang tersebut."

Eksekusi Dengan menggunakan titel eksekutorial yaitu dimana kreditor pemegang Hak Tanggungan dapat melakukan penjualan objek Hak Tanggungan dengan memperhatikan ketentuan Hukum Acara Perdata yang berlaku. (Saleh, 2016). Penjualan objek jaminan tersebut melalui penjualan umum oleh Pejabat Kantor lelang dimana pelaksanaannya menurut ketentuan dan tata cara yang telah ditetapkan, baik Kantor Lelang Negara atau Balai Lelang Swasta yang telah mendapat izin. 
Dalam eksekusi objek jaminan Hak Tanggungan cara ketiga, yaitu eksekusi dengan penjualan di bawah tangan seperti yang diatur dalam Pasal 20 ayat (2) UUHT yang menyatakan atas kesepakatan pembeli dengan pemegang Hak Tanggungan, maka penjualan objek Hak Tanggungan dapat dilaksanakan di bawah tangan, bilamana dengan cara tersebut akan dapat diperoleh harga tertinggi yang menguntungkan semua pihak. Pelaksanaan penjualan sebagaimana dimaksud pada Pasal 20 ayat (2) UUHT hanya dapat dilakukan setelah lewat waktu 1 (satu) bulan sejak pemberitahuan secara tertulis oleh pemberi dan/atau pemegang hak tanggungan kepada pihak-pihak yang berkepentingan dan diumumkan sedikitnya dalam 2 (dua) surat kabar yang beredar di daerah yang bersangkutan dan/atau media massa setempat, serta tidak ada pihak yang menyatakan keberatan. (Suci dan Poesoko, 2009:138).

Pencoretan Hak Tanggungan pada buku tanah oleh Kantor Pertanahan dapat dilaksanakan setelah adanya surat keterangan lunas yang dikeluarkan oleh pihak bank sebagai kreditor pemegang hak tanggungan yang berisikan permohonan agar catatan hak tanggungan segera dihapus karena utangnya telah lunas. Dengan dikeluarkannya Surat Roya, maka seluruh berkasberkas, yaitu sertifikat asli tanah dan Sertifikat Hak Tanggungan dikembalikan kepada pemilik dan pemilik bisa mengajukan penghapusan catatan yang ada disertifikat mengenai Pembebanan Hak Tanggungan kepada Kantor Pertanahan.

\section{SIMPULAN}

Pemberian kredit pada PT. Bank Mestika Dharma,Tbk dimulai dari permohonan debitur kepada bank dengan mengisi form permohonan kredit dengan menyertakan beberapa data yang diperlukan, kemudian dilanjutkan dengan keputusan kredit setelah sebelumnya dilakukan analisis terhadap semua data yang diberikan debitur termasuk penilaian terhadap 5C debitur terlebih dahulu serta membandingkan kemampuan membayar debitur dengan jumlah pinjaman yang diajukan. Setelah adanya keputusan dari pihak bank maka akan dilanjutkan dengan pembuatan perjanjian kredit (PK) dan pengikatan terhadap objek jaminan kredit.

Dalam PK dan APHT dicantumkan segala sesuatu tentang kredit dan pelaksanaanya. Jumlah utang si debitur, tata cara pelunasannya, berikut pula hal-hal yang menjadi kesepakatan bersama seperti hak dan kewajiban masing-masing pihak juga tak lupa solusi yang diambil jika debitur wanprestasi (cidera janji) dalam membayar kewajibannya. Kemudian oleh PPAT yang diberikan kuasanya oleh bank, mengajukan pemasangan Hak Tanggungan dan pencatatan di Kantor Pertanahan untuk kemudian dikeluarkannya Sertifikat Hak Tanggungan.

Dalam hal pemenuhan haknya, kreditor pemegang Hak Tanggungan akan didahulukan (preferen dan separatis) serta diistimewakan dari kreditor lainnya, dalam konteks sebesar nilai hak tanggungan. Eksekusi objek jaminan Hak Tanggungan dapat ditempuh melalui 3 (tiga) cara, yaitu: (1) parate eksekusi; (2) titel eksekutorial; dan (3) penjualan di bawah tangan untuk pemenuhan kewajiban debitur kepada bank sebagai kreditor.

\section{DAFTAR PUSTAKA}

Djumhana, M., (2000), Hukum Perbankan di Indonesia, Bandung: Citra Aditya Bakti.

Fauzi, A. (2019). Karakter Hukum Bangunan Gedung Sebagai Jaminan Utang. DOKTRINA: JOURNAL OF LAW, 2(1), 13-31. doi:https://doi.org/10.31289/doktrina.v2i1.2347

Fuady, M, (2002), Hukum Perkreditan Kontemporer, Bandung: PT Citra Aditya Bakti.

Fuady, M. (2013). Hukum Jaminan Utang. Jakarta: Erlangga.

Handayani, S. (2015). "Pendaftaran Hak Atas Tanah Asal Leter C, Girik dan Petuk D Sebagai Alat Bukti Permulaan Di Kabupaten Sleman Daerah Istimewa Yogyakarta.” Jurnal Repertorium. Surakarta: UNS Pers. Edisi 2. Juli-Desember. Tahun II.

Hermansyah, (2014), Hukum Perbankan Nasional Indonesia, Edisi Revisi, Jakarta: Kencana.

Jamilah. (2017). Pelaksanaan Pasal 1131 KUHPerdata atas Jaminan Benda Milik Debitur. JURNAL MERCATORIA, 10(2), 137-159. doi:https://doi.org/10.31289/mercatoria.v10i2.1150

Muhammad, S, (2016), Kepastian Hukum Dalam Penyelesaian Kredit Macet Melalui Eksekusi Jaminan Hak Tanggungan Tanpa Proses Gugatan Pengadilan, Jakarta: Prenadamia Group. 
Evelin Wijaya, Fendy \& Aisyah, Yuridis Pemberian Kredit Bank dengan Jaminan Hak Tanggungan pada PT. Bank

Mestika Dharma, Medan

Nainggolan, P.N.H., dan Isnaini, (2012), Analisis Terhadap Penetapan No: 01/Pen.Pdt.G/ Eks/HT/2010/ PN-PMS tentang Eksekusi Barang Jaminan oleh Bank dalam Penyelesaian Kredit Bermasalah, Mercatoria, 5 (1): 56-65

Rahman, H., (1995), Aspek-Aspek Pemberian Kredit Perbankan di Indonesia, Bandung: Citra Aditya Bakti.

Raymond P. Kent dan Thomas Suyatno, 1991, Dasar-Dasar Perkreditan, Jakarta: Gramedia Pustaka Utama.

Sari, A.K. (2015). "Perlindungan Hukum Terhadap Kreditor Pemegang Hak Tanggungan yang tidak didaftarkan di Kantor Pertanahan.” Jurnal Repertorium. Surakarta: UNS Pers. Edisi 3. Januari-Juni. Tahun II.

Satrio, J., (2007), Hukum Jaminan Hak-hak Jaminan Kebendaan, Bandung: PT Citra Aditya Bhakti.

Sipayung, I.M., Kamello, T., Marlina \& Kartika, A. (2019). Perjanjian Jaminan Fidusia Kaitan dengan Penyidikan Tindak Pidana Perlindungan Konsumen. ARBITER: Jurnal Ilmiah Magister Hukum. 1(2): 157-166.

Subekti, (1990), Pelaksanaan Perikatan, Eksekusi Riil dan Uang Paksa dalam Penemuan Hukum dan Pemecahan Masalah Hukum, Proyek Pengembangan Teknis Yustisial, Jakarta: MARI.

Subekti, (1991), Jaminan-jaminan untuk Pemberian Kredit Menurut Hukum Indonesia, Bandung: Citra Aditya Bakti.

Subekti, R, (1995), Aneka Perjanjian, Bandung : PT. Citra Aditya Bakti.

Suci, I.D.A., dan Poesoko, H., (2009), Hak Kreditur Separatis dalam Mengeksekusi Benda Jaminan Debitur Pailit, Yogyakarta: LaksBang PRESSindo.

Sutedi, A, (2010), Hukum hak Tanggungan, Jakarta: Sinar Grafika.

Trisadini, P., \& Usanti, A.S., (2017), Hukum Perbankan, Jakarta : Kencana.

Usman, R, (2001), Aspek-aspek Hukum Perbankan di Indonesia, Jakarta: PT. Gramedia Pustaka Utama.

Undang-Undang

Undang-Undang Nomor 4 Tahun 1996 tentang Hak Tanggungan.

Undang-Undang Nomor 10 Tahun 1998 tantang Perubahan Atas Undang-Undang Nomor 7 Tahun 1992 tentang Perbankan. 